\title{
What is the potential of site units applied into forestry management in Slovakia to describe production of beech stands?
}

\section{Bošel'a}

\author{
Wood and Forestry Faculty, ČZU, Kamýcká 1176, 16521 Praha 6-Suchdol, Czech Republic, \\ bosela@fld.czu.cz \\ National Forest Centre - Forest Research Institute Zvolen, T.G. Masaryka 22, 96092 Zvolen, Slovakia, \\ bosela@nlcsk.org
}

Abstract: Bošel'a, M. 2012: What is the potential of site units applied into forestry management in Slovakia to describe production of beech stands? - Beskydy, 5 (2): 99-110

\begin{abstract}
A high number of site units have been recognized so far in Slovakia region. Site units are to reflect diverse ecological condition and production capability of different sites. In Slovakia, there is a huge number of management units (forest site type, management units of forest site types) and ecological site units (forest site type groups), but more detailed and objective analysis and comparison of their ecological and production properties have not been performed yet. The main aim of this paper is thusq quantification of beech growth potential in selected basic and forestry-applied site units used in Slovakia forest management. Data collected within National Forest Inventory in Slovakia (2005-2006) were used for the analysis. Regression models of mean stand diameter and mean stand height were developed. Intercept of models were compared between sites using the t-test. Site units were merged into several groups in terms of beech growth - As for the altitudinal vegetation zones, three groups were identified, in which the beech productivity was rather homogenous. $3^{\text {rd }}, 4^{\text {th }}$, and $5^{\text {th }}$ altitudinal vegetation zones were grouped into the first group. The second group ( $2^{\text {nd }}$ AVZ) includes poorer sites at lower altitudes (low precipitation as a limiting factor) with lower beech productivity. The third group includes sites at higher altitudes $\left(6^{\text {th }}\right.$ AVZ), where the temperature limits beech growth. In terms of soil properties, two or three groups can be recognized. The first one includes hemioligotrophic and heminitrophilous sites, while the calciphile sites showed lower beech growth potential.
\end{abstract}

Keywords: site classification, site productivity, beech, regression model

\section{Introduction}

Forest site classification is a method for dividing an area with high variability of ecological, climatic and production conditions into moreless homogeneous parts. Specialists from all over the world have been dealing with classifying the sites into homogeneous parts as for an ecological, climatic, production conditions or its combination (Zlatník 1959, 1976, Hančinský 1972, 1974, 1983, 1990, Randuška et al. 1986, Ellenberg 1974, Bryan 2006, Cajander 1909, 1949, Ray 2001, Bajzak, Roberts 1996, Rowe 1996, Kai et al. 1999, and others). The reason why the people have dealt with such classifications was to set up similar management measures within the site units. It is needed for management decisions making and for assessment of management models as well.

Site units should reflect ecological as well as production conditions. However, the problem integrates many physical site factors. The site factors are not only interdependent but are also dependent in part upon the forest, which is itself a major site-forming factor. Because of these interactions, the simple regression technique of estimating site quality from an evaluation 
of a few important site factors, important as it is in practical forest ecology, can only be approximate (Barnes et al. 1998). Productivity, or actual site quality, may be measured directly for a few forests where accurate long-term records of stand development and growth have been maintained. However, it can only be estimated indirectly by one or more of the alternatives, as follows (Barnes et al. 1998):

Forest vegetation - tree height (site index method), ground vegetation (indicator species and species groups), overstory and groundcover vegetation in combination;

Physical environment factors - climate, physiography, and soil survey and soil-site methods

Multiple-factor and multiple-scale approaches (using some or all of the above factors, disturbance regime, and forest land-use history.

\section{Forest site typology and classification in Slovakia}

Classification of the forest ecosystems is based on the forest typology drafted out by professor Zlatník, who was charged to create mapping units for reconstruction of the natural vegetation in 1948. In 1972, Hančinský remade and completed characteristics of the forest types. Site units and its number are as follows:

Basic units: Forest site types - FST (number is 365); Forest site type groups - FSTG (number is 92); Altitudinal vegetation zone - AVZ (number is 8); Edaphic-trophic orders and interorders $\mathrm{EO}$ (number is 8).

Higher-hierarchy units: Management units of forest site types - FSTMU (number is 160); Forest cover types - Management units of forest cover types - FCTMU (based on a tree species composition, number is cca 98).

Nowadays, Slovak forestry uses the site maps and the relevant GIS layer based on the forest site type units (it has been elaborated by National Forest Centre stuff). The site index, defined as average tree height at the age - 100 years (or 30 years for fast-growing tree species, respectively) has being used for the assessment of the site quality. Growth modelling and simulators (e.g. SIBYLA) are becoming meaningful in classification of forest sites or ecosystems and its development prediction (Fabrika 2003).

Problems and difficulties of current forest typology in Slovakia are as follow: (i) large number of classification units; (ii) which brings some difficulties in determination and recognizing of the forest site types and other units during field work; (ii) insufficient knowledge on sitemapping of artificially changed forests; (iii) little tangible similarity of a forest stand productivity within the typological units.

The difficulties in determination of the vegetation units are based especially on the typification of the various qualitative, quantitative, topical, choric and dynamic manifestations of chtonophytical taxons (Kukla 1993b). All ecological units of geobiocen types can be determined only indirectly at the present, by means of the floristic analysis and vegetation classification though it is required to confront the result with characteristics of the abiotic environment. The complete analysis of ecological factors influencing a nature of ecosystems has not been performed yet (Kukla 1993a).

\section{Definition of particular site units analyzed in the paper}

Forest site types (FST): represent basic "abstract" units of geobiocenologic classification defined as a site type with permanent ecological conditions. Each particular forest site type is a type of a natural geobiocenosis comprising all its developmental stages and to a various degree and nature altered associated geobiocenoses and geobiocenoides (including their developmental stages) occurring on the sites of a particular natural geobiocenosis (Schwarz 2009, Zlatník 1976).

Management units of forest site types (FSTMU, Schwarz 2009): they group forest site types with similar natural conditions and similar wood production capability (Križová 1995). FSTMUs, which were analyzed here, are:

211 - Oak - beech forests

302 - Calcareous beech - oak forests

305 - Acid beech - oak forests

310 - Fertile beech - oak forests (drier type)

311 - Fertile beech - oak forests

313 - Moist beech - oak forests

316 - Beech - oak forests with lime on rocky soils

402 - Calcareous beech forests

410 - Fertile beech forests (drier type)

411 - Fertile beech forests

502 - Calcareous beech - fir forests

511 - Fertile beech - fir forests

516 - Beech - fir forests on rocky soils

Altitudinal vegetation zones (AVZ): reflect a sequence of differences in natural vegetation depending on differences in climate of elevation and exposition (Buček, Lacina 1999). They are defined on the basis of ediphicators combination (combination of dominant climax tree species, Zlatník 1976). In this analysis we selected those zones where we had enough plots for 
analysis: 2 - beech-oak; 3 - oak-beech; 4 - beech; 5 - beech-fir; 6 - fir-beech-spruce

Edaphic-trofic orders (EO): EO are defined with respect to soil properties, considering fertility, soil acidity, humification type, soil depth, soil skeleton, moisture-holding capacity, and others (Križová 1995). Units selected for our analyses are:

A/B-hemioligotrophic; B-mesotrophic; B/Cheminitrophilous; D-calciphile

\section{Material and method}

\section{Sampling techniques and field methods}

The data collected during the National Forest Inventory in 2005 and 2006 (Šmelko et al. 2006) were used for this analysis (Fig.1). For our analysis 737 inventory plots (IP) from the total 1419 plots were selected applying the following criteria: (i) the number of measured trees on the plot was 3 and higher; (ii) tree species was to be beech and that species, which have the same growth properties like a beech (Halaj et al. 1980a, 1980b). Counts of selected IP within the each site units are presented in Tab. 1 . The plots were established in regular grid of $4 \times 4 \mathrm{~km}$ over the entire forests of Slovakia. The area of IP is $500 \mathrm{~m}^{2}$. If the different growth stages, different age, different site conditions or different tree species next to each other were recognized the IP was divided into two or more parts to be more homogeneous. Site units (forest site types, which are described in the introduction) on each IP were recognized by specialists on forest typology). Code of forest site type consists of 4 numbers where the first one means a forest vegetation zone, the second one is edaphic-trophich order and the last two numbers indicated an order of forest site types within the group. It is possible to derive superstructure units from this code, which are on higher hierarchical level of the classification system. Thus, the forest site type is the basic unit, which can be grouped into higher hierarchical level (group of forest site types, edaphic-trophic order, forest vegetation zones, and its combinations).

\section{Statistical analysis}

Model definition - usually the mean or top height of a species is modelled over the stand age, because the growth is time-dependent. However, a problem can arise if the stand age is only estimated by some approximation methods

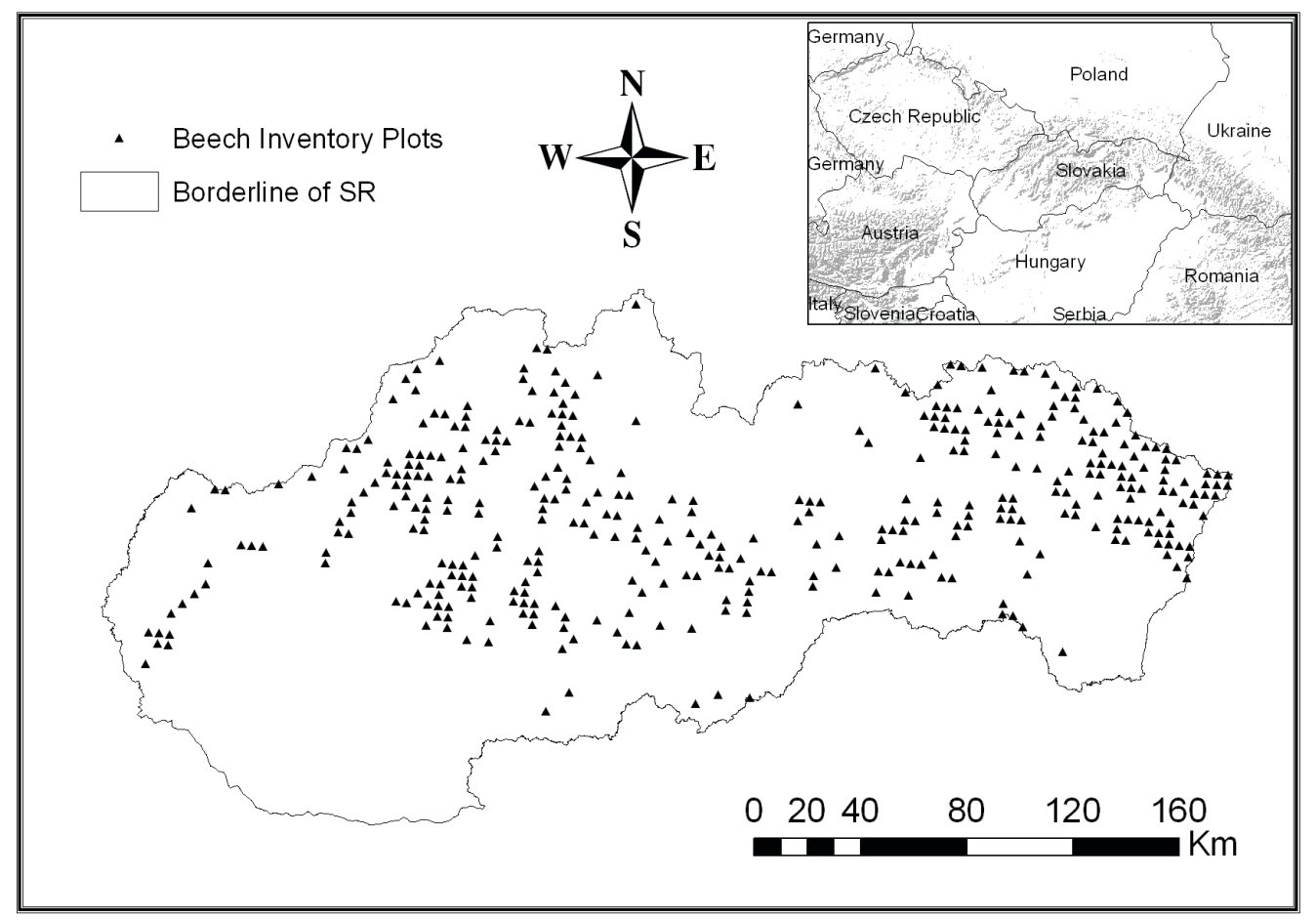

Fig. 1: Spatial distribution of the inventory plot sused for the study. 
(e.g. the number of whorls in coniferous). Thus, the biased estimation of the stand age increases the variance of the relationship between stand age and stand height. Moreover, when small number of trees occurs on a plot, the calculation of the top height could have biased the estimation due to the extreme values. Instead, I built regression models of mean diameter $\left(D_{g}\right)$ and mean height $\left(\mathrm{H}_{\mathrm{g}}\right)$ using the Michajl regression model (Šmelko et al. 1992). Since the DBH is measured at $1.3 \mathrm{~m}$ height the regression starts at this value:

$$
\mathrm{H}_{\mathrm{g}}=1.3+\mathrm{a} \mathrm{e}^{-\mathrm{b} / \mathrm{Dg}}
$$

Where:

$\mathrm{Hg}$ - mean stand height

Dg - mean stand diameter

a, b-regression coefficients

This regression model provided the best fitting by the method of least squares. Applying this equation, models for each selected site unit were derived. The STATISTICA and R software were used to buld the models (StatSoft, Inc. 2011, R Development Core Team 2012). Subsequently, regression curves (growth development curves) were constructed to show the differences between site units.

The mean height was derived as weighted average. The weight was a basal area at breast height. The mean diameter was derived as the quadratic mean.

Test of hypothesis on equality of regression parameters between two models - Student's t-test was employed to test the null hypothesis that the difference in intercepts between two site units is random at $\alpha=0.05$ level of significance:

$$
t_{(d f)}=\frac{b_{i(1)}-b_{i(2)}}{S_{\left(b_{i(1)}-b_{i(2)}\right)}}
$$

Where $b_{i(1)}$ and $b_{i(2)}$ refers to regression coefficients, and $S_{\left(b_{i(1)}-b_{i(2)}\right)}$ is the standard error of

the difference between the two means and is calculated as follow:

$$
S_{\left(b_{i(1)}-b_{i(2)}\right)}=\sqrt{\frac{\left(n_{1}-1\right) S_{1}^{2}+\left(n_{2}-1\right) S_{2}^{2}}{n_{1}+n_{2}-2}\left(\frac{1}{n_{1}}+\frac{1}{n_{2}}\right)}
$$

\section{Results}

Regression analysis for selected site units was performed and regression models are presented in Tab.l. Results for vegetation zones, edapfic-trophic orders and management units of forest site types are presented respectively. Regression coefficients for all site units' height models were significant and regression model used for this purpose gave the best fit. Percentage error of regression coefficient $a$ ranges from $3 \%$ to $13 \%$ and it depends upon the sample size and mainly upon height variability. Percentage error of regression coefficient $b$ ranges from $4 \%$ to $23 \%$. The intercept is set to 1.3 because of diameter measuring in high of $1.3 \mathrm{~m}$ (breastheight). Correlation coefficient ranges from 0.69 to 0.92 . Correlation and height variability shows the homogeneity rate of site condition with respect to beech production. When considering management units of forest site types the best correlation as well as lowest height variability is achieved within the unit number 516 (Stony fir-beech forests), 410, 310 (fresh beech forests). As for the edaphic-trophic order the best correlation is in A/B (hemioligotrophic) and B/C (heminitrophilous), and in fourth altitudinal vegetation zone. Beech in these site units reaches a highest production and high competitive capability. These facts cause the lower mean height variability. The lowest correlation and higher mean height variability is in extreme site units (6th forest vegetation zone, D edaphictrophic order, 302, 305 and 316 management group of forest site types). In these site units the beech has a low competitive capability and its production is lowest and depends on other factors (tree species composition, climatic factors, topographic, soil properties, and others).

Subsequently the curves for all selected site units were constructed. In Fig. 2 the curves for altitudinal vegetation zones are presented. As the ecological conditions within the zones are various the IP where the mezotrophic order "B" was identified were selected for the analysis. We can see that the three groups are clustered with significant difference between one another (Fig. 2). The first consists of third, fourth and fifth altitudinal vegetation zones. Productivity of beech in this group is higher than in another one. Beech in these vegetation zones has a growth optimum as well as a highest competitive capability (Pagan 1999). 
Tab. 1: Parameters of regression model for particular site units and its precision.

\begin{tabular}{|c|c|c|c|c|c|c|c|c|c|c|c|}
\hline \multirow{2}{*}{\multicolumn{2}{|c|}{ Site unit }} & \multicolumn{5}{|c|}{$\mathrm{a}$} & \multicolumn{4}{|c|}{ b } & \multirow{2}{*}{$\mathbf{R}^{2}$} \\
\hline & & $\mathbf{n}$ & value & st. error & $\mathbf{t}$ & $\mathrm{p}$ & value & st. error & $t$ & $p$ & \\
\hline \multirow{5}{*}{$\mathbb{Z}^{N}$} & 2 & 68 & 30.63 & 2.011414 & 15.23 & $<0.001$ & 14.51817 & 1.26835 & 11.45 & $<0.001$ & 0.64 \\
\hline & 3 & 249 & 41.64 & 1.326089 & 31.40 & $<0.001$ & 18.24610 & 0.81246 & 22.46 & $<0.001$ & 0.69 \\
\hline & 4 & 149 & 41.71 & 1.405984 & 29.67 & $<0.001$ & 18.97373 & 0.93927 & 20.20 & $<0.001$ & 0.76 \\
\hline & 5 & 55 & 42.22 & 2.897367 & 14.57 & $<0.001$ & 20.34637 & 1.80784 & 11.25 & $<0.001$ & 0.71 \\
\hline & 6 & 16 & 34.23 & 3.756960 & 9.11 & $<0.001$ & 16.73852 & 3.06361 & 5.46 & $<0.001$ & 0.72 \\
\hline \multirow{4}{*}{ ○ే } & $\mathrm{A} / \mathrm{B}$ & 23 & 45.07 & 4.450845 & 10.13 & $<0.001$ & 21.20483 & 2.62860 & 8.07 & $<0.001$ & 0.76 \\
\hline & B & 54 & 42.22 & 2.897367 & 14.57 & $<0.001$ & 20.34637 & 1.80784 & 11.25 & $<0.001$ & 0.71 \\
\hline & $\mathrm{B} / \mathrm{C}$ & 22 & 46.12 & 3.065660 & 15.04 & $<0.001$ & 21.73709 & 1.92137 & 11.31 & $<0.001$ & 0.83 \\
\hline & $\mathrm{D}$ & 16 & 36.50 & 5.068315 & 7.20 & $<0.001$ & 16.46429 & 3.11863 & 5.28 & $<0.001$ & 0.64 \\
\hline \multirow{13}{*}{ 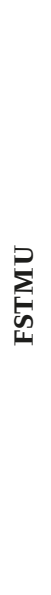 } & 211 & 25 & 32.83 & 3.114080 & 10.54 & $<0.001$ & 14.93144 & 1.927371 & 7.75 & $<0.001$ & 0.69 \\
\hline & 302 & 21 & 32.92 & 4.293451 & 7.67 & $<0.001$ & 15.38761 & 3.064381 & 5.02 & $<0.001$ & 0.56 \\
\hline & 305 & 23 & 29.15 & 3.782047 & 7.71 & $<0.001$ & 12.77003 & 3.062962 & 4.17 & $<0.001$ & 0.48 \\
\hline & 310 & 81 & 43.50 & 2.242407 & 19.40 & $<0.001$ & 18.58488 & 1.286969 & 14.44 & $<0.001$ & 0.76 \\
\hline & 311 & 98 & 41.80 & 1.933276 & 21.62 & $<0.001$ & 17.20133 & 1.214654 & 14.16 & $<0.001$ & 0.67 \\
\hline & 313 & 21 & 44.30 & 4.275543 & 10.36 & $<0.001$ & 21.62224 & 2.351202 & 9.20 & $<0.001$ & 0.76 \\
\hline & 316 & 22 & 48.52 & 4.855225 & 9.99 & $<0.001$ & 22.86128 & 2.392518 & 9.56 & $<0.001$ & 0.71 \\
\hline & 402 & 26 & 35.64 & 3.922063 & 9.09 & $<0.001$ & 17.96713 & 2.494601 & 7.20 & $<0.001$ & 0.67 \\
\hline & 410 & 45 & 47.12 & 2.920833 & 16.13 & $<0.001$ & 21.50786 & 1.787856 & 12.03 & $<0.001$ & 0.81 \\
\hline & 411 & 57 & 40.83 & 2.219807 & 18.39 & $<0.001$ & 17.90290 & 1.528112 & 11.72 & $<0.001$ & 0.71 \\
\hline & 502 & 29 & 40.98 & 4.011083 & 10.22 & $<0.001$ & 18.66089 & 2.294163 & 8.13 & $<0.001$ & 0.71 \\
\hline & 511 & 55 & 41.41 & 2.639069 & 15.69 & $<0.001$ & 19.55546 & 1.755404 & 11.14 & $<0.001$ & 0.71 \\
\hline & 516 & 28 & 48.96 & 3.276324 & 14.94 & $<0.001$ & 23.55288 & 1.840936 & 12.79 & $<0.001$ & 0.85 \\
\hline
\end{tabular}

Note: 1 - Vegetation zone stratified by edaphic-trophic order B

2 - Edaphic-trophic order stratified by vegetation zone $5^{\text {th }}$

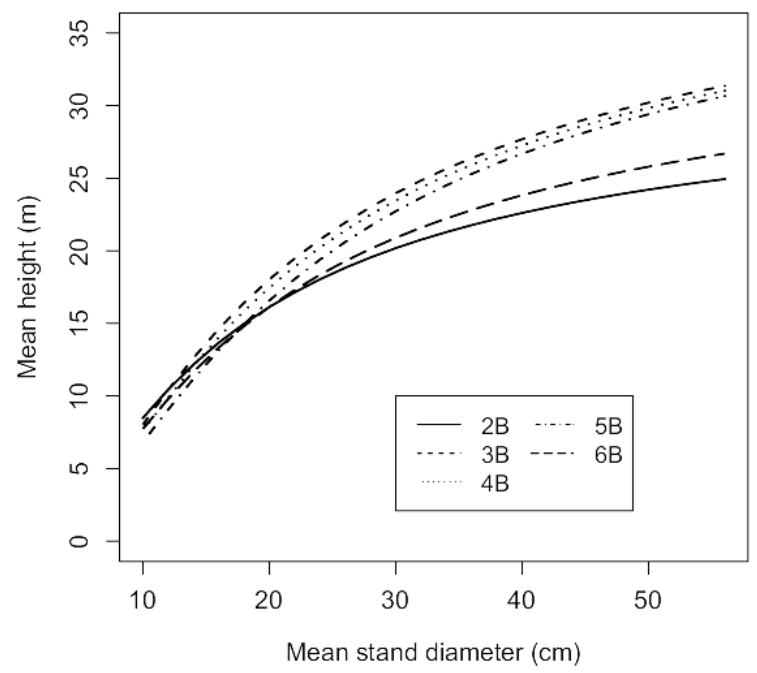

Fig. 2: Mean height-to-mean diameter curves for altitudinal vegetation zones. 
The second group consists of $2^{\text {nd }}$ AVZ and the third one of $6^{\text {th }}$ AVZ (despite the significant difference - see Tab. 2). Limiting conditions for beech productivity (in terms of beech ecological amplitude) occur in these zones (while in the $2^{\text {nd }} \mathrm{AVZ}$ it is precipitation, in the $6^{\text {th }} \mathrm{AVZ}$ it is temperature). We can state that it would be possible in terms of beech productivity to group the altitudinal vegetation zones into three groups $\left(3^{\text {rd }}, 4^{\text {th }}\right.$ and $5^{\text {th }}$ into the first, then $2^{\text {nd }}$ and $6^{\text {th }}$ AVZ would be the next two units). In the first group, the mean height at the diameter of $56 \mathrm{~cm}$ is approximately of $31 \mathrm{~m}$, in the second $26 \mathrm{~m}$ and in the third one $24 \mathrm{~m}$. The difference between them becomes a visible and significant at the diameter of $25 \mathrm{~cm}$ (between 20 and $30 \mathrm{~cm}$ ).

As the altitudinal vegetation zones reflect mainly climatic conditions and natural tree species distribution, and do not reflect a soil conditions, the edaphic-trophic orders, which reflect a soil conditions were selected for the analysis. In the figure 3 we can see that the $\mathrm{EO}$ "B/C" showed a highest and EO "D" lowest beech productivity. Sites within the EO "D" have extreme conditions (calcareous sites on rockiness steep slopes, shallow soils), and forests on these sites have a low density (Križová, Nič 1991). Sites within the "B/C", "B" and "A/B" EO are of fertile ones.

When compared each other, the differences between " $\mathrm{D}$ " and other EO were found as a statistically significant. If we want to group some of these site units with respect to beech productivity, we could create two or three groups. First one would consists of "B/C" and "A/B", second one of " $\mathrm{B}$ " (this unit could be grouped into the first), and last one of "D". EO " $\mathrm{B}$ " and " $\mathrm{D}$ " have lower correlation and higher mean-height variability. This fact points to wider range of ecological conditions in these site units. EO "A/B" and "B/C" showed the correlation coefficient of 0.87 and 0.91. The high beech growth capability in $\mathrm{EO}$ "A/B" is interesting, because the soils in this $\mathrm{EO}$ are less fertile (hemioligotrophic) compared to $\mathrm{B}$ or $\mathrm{B} / \mathrm{C}$. The difference between $\mathrm{EO}$ "B/C" and " $\mathrm{D}$ " becomes visible and significant at the diameter of $25 \mathrm{~cm}$. These results correspond with unit's description (Zlatník 1976, Hančinský 1972).

Tab. 2: p-values from t-test of differneces in intercepts between altitudinal vegetation zones.

\begin{tabular}{cccccc}
\hline & $\mathbf{2}$ & $\mathbf{3}$ & $\mathbf{4}$ & $\mathbf{5}$ & $\mathbf{6}$ \\
\hline $\mathbf{2}$ & - & 0.0000 & 0.0000 & 0.0000 & 0.0059 \\
$\mathbf{3}$ & - & - & 0.9534 & 0.6036 & 0.0000 \\
$\mathbf{4}$ & - & - & - & 0.6728 & 0.0000 \\
$\mathbf{5}$ & - & - & - & - & 0.0000 \\
$\mathbf{6}$ & - & - & - & - & - \\
\hline
\end{tabular}

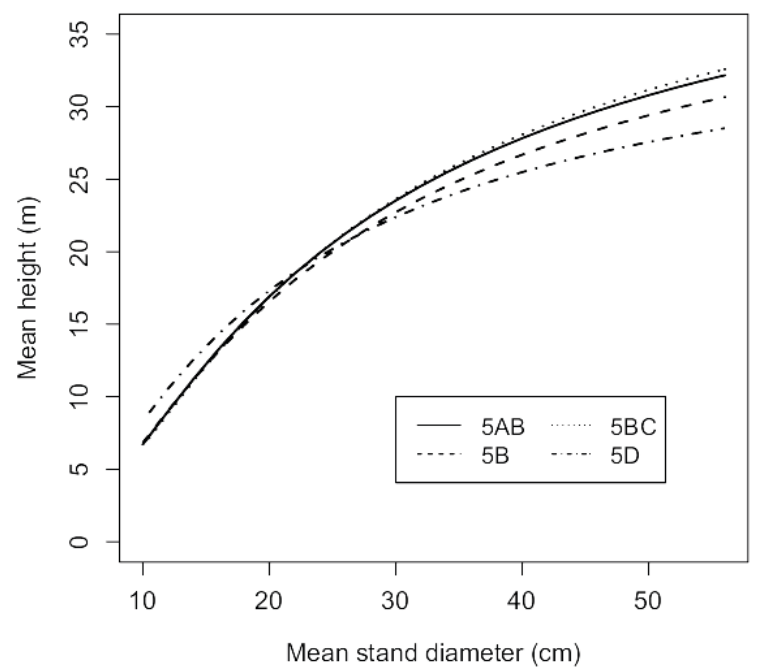

Fig. 3: Mean height-to-mean diameter curves for edaphic-trophic orders. 
Last site units, for which the regression models were created, are management units of forest site types (Fig. 6). As in the case of AVZ, also in this case, the two tangible different groups can be recognized. Units such as $310,311,313,410$, 411, (502), 511, and 516 could be grouped into first one and other units $(211,302,305$, and 402) into second one. Sites of the first group are fertile ones and make favourable conditions beech growth. Site of second group has poor soils limiting the beech growth (in 302, 305 and 402 it is poor soil, while in 211 it is the lack of precipitation). In the first group, the mean height at mean diameter reaches approximately $32 \mathrm{~m}$ and in the second group it is about $25 \mathrm{~m}$. The similar result was revealed for AVZ. Despite the unit 502 (calcareous soils) is characterized by its poor soils, the beech growth seems better than in other units on poor soils. This can be explained by the amount of precipitation, which makes the site more favourable to beech trees.

When compared two groups within all site units (AVZ, EO, FSTMU), fertile one and poor one, the regression curves are crossed at the diameter of $15 \mathrm{~cm}$ up to $25 \mathrm{~cm}$. It means that the beech on fertile sites reaches a lower height than the beech on poorer sites (at the same diameter) as long as the diameter is approximately $15 \mathrm{~cm}$ up to $25 \mathrm{~cm}$. However, the number of plots for young stands is small leading to the large standard error, so it cannot be considered as the statistical difference. When the diameter is over 15$25 \mathrm{~cm}$, beech on the fertile sites reaches a higher mean height and thus a higher productivity.

Generally, considering the elevation and soil properties, four groups could be clearly distinguished: (1) fertile sites at the low-elevation (or altitudinal vegetation zones inferior); (2) poor sites at low-elevation; (3) fertile sites at high-elevation (or altitudinal vegetation zones superior); (4) poor sites at high-elevation.

\section{Discussion}

Determination and characterization of forest site type is influenced by many factors. Basis for determination within Zlatnik approach are type of phytocoenosis (on the basis of phytocoenological material from permanent research plots - PRP). The forest site types are subsequently confronted with soil and other environment description. The PRPs in management forests are than confronted with parallel PRPs in natural or virgin (primeval) forests to be reconstructed.

Tab. 3:p-values from t-test of differneces in intercepts between edaphic-trophic orders.

\begin{tabular}{ccccc}
\hline & AB & B & BC & D \\
\hline AB & - & 0.2321 & 0.6118 & 0.0006 \\
B & - & - & 0.0079 & 0.0004 \\
BC & - & - & - & 0.0001 \\
D & - & - & - & - \\
\hline
\end{tabular}

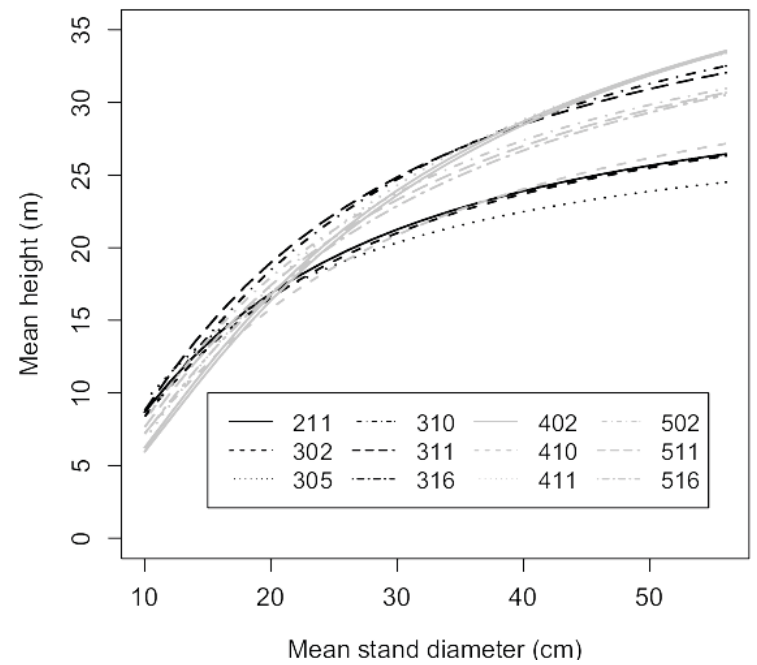

Fig. 4: Mean height-to-mean diameter curves for management units of forest site types. 
Tab. 4: p-values from t-test of differneces in intercepts between management units of forest site types.

\begin{tabular}{cccccccccccccc}
\hline & 211 & $\mathbf{3 0 2}$ & $\mathbf{3 0 5}$ & $\mathbf{3 1 0}$ & $\mathbf{3 1 1}$ & $\mathbf{3 1 3}$ & $\mathbf{3 1 6}$ & $\mathbf{4 0 2}$ & $\mathbf{4 1 0}$ & $\mathbf{4 1 1}$ & $\mathbf{5 0 2}$ & $\mathbf{5 1 1}$ & $\mathbf{5 1 6}$ \\
\hline $\mathbf{2 1 1}$ & - & 0.962 & 0.058 & 0.000 & 0.000 & 0.000 & 0.000 & 0.157 & 0.000 & 0.000 & 0.000 & 0.000 & 0.000 \\
$\mathbf{3 0 2}$ & - & - & 0.095 & 0.000 & 0.002 & 0.000 & 0.000 & 0.238 & 0.000 & 0.001 & 0.001 & 0.001 & 0.000 \\
$\mathbf{3 0 5}$ & - & - & - & 0.000 & 0.000 & 0.000 & 0.000 & 0.004 & 0.000 & 0.000 & 0.000 & 0.000 & 0.000 \\
310 & - & - & - & - & 0.272 & 0.539 & 0.000 & 0.000 & 0.008 & 0.055 & 0.061 & 0.134 & 0.000 \\
311 & - & - & - & - & - & 0.045 & 0.000 & 0.000 & 0.000 & 0.460 & 0.519 & 0.770 & 0.000 \\
$\mathbf{3 1 3}$ & - & - & - & - & - & - & 0.084 & 0.000 & 0.232 & 0.145 & 0.160 & 0.235 & 0.038 \\
$\mathbf{3 1 6}$ & - & - & - & - & - & - & - & 0.000 & 0.556 & 0.002 & 0.003 & 0.005 & 0.846 \\
$\mathbf{4 0 2}$ & - & - & - & - & - & - & - & - & 0.000 & 0.017 & 0.013 & 0.009 & 0.000 \\
$\mathbf{4 1 0}$ & - & - & - & - & - & - & - & - & - & 0.000 & 0.000 & 0.001 & 0.236 \\
$\mathbf{4 1 1}$ & - & - & - & - & - & - & - & - & - & - & 0.914 & 0.701 & 0.000 \\
$\mathbf{5 0 2}$ & - & - & - & - & - & - & - & - & - & - & - & 0.837 & 0.000 \\
$\mathbf{5 1 1}$ & - & - & - & - & - & - & - & - & - & - & - & - & 0.000 \\
$\mathbf{5 1 6}$ & - & - & - & - & - & - & - & - & - & - & - & - & - \\
\hline
\end{tabular}

However, the determination (analysis) of production capability within forest site types has not been conducted, yet. Determination of production capability and growth development of tree species, which are typical for particular forest site types, are the basis assumption for utilization of the forest typology and classification in a management planning (Vyskot et al. 1971).

Many our and foreign specialists have dealt with study of wood production within forest site types. Halaj et al. (1990) in their study of rotation age (maturity or exploitability) of tree species revealed a high variability of production within a particular management units of forest site types, when the variability of site index within units was higher than variability between them. Mráz (1955 in Vyskot 1971) dealt with a production capability of site types, which are defined by phytocoenology. Volume production determination is based on site indexes. Mezera (1959 in Vyskot 1971) compared particular site types of tree species according to growth development curves. Ettera (1949, 1952 in Vyskot 1971) used a top height as an indicator of total volume production in groups of forest site types of Fagetum typicum and in Abieto-Fagetum. Koch (1955 in Vyskot 1971) derived a frequency distribution of tree diameter within the site units for spruce stands in northern part of Oberschwaben.

Merganič et al. (2003) investigated an effect of elevation on spruce growth development in Babia Hora and revealed the high relationship between top stand height $\left(\mathrm{h}_{10 \%}\right)$ and elevation for virgin forests in Babia Hora (Norway spruce), when the coefficient of determination was $\mathrm{r}^{2}=0.819$. Beech productivity depending especially on elevation was also revealed in our study.

Development of trees number depends on tree species as well as on site quality. The tree number at younger stands is higher on poorer sites than on fertile ones at the same age (Vyskot et al. 1971). Crop density of top stand layer is lower on poorer sites and it results to faster height growth than on fertile sites. But, when the stand on poorer site reaches a particular mean stand diameter (as for the beech stands it is15$25 \mathrm{~cm}$ ) the height growth will slow down and stands on fertile sites will reach a higher mean height at the same diameter. Growth curve, which represents a relationship between tree diameter and height, has a steep form in young forest stands and on fertile sites, and the curve in older stands and on poorer sites is flatter (Šebík, Polák 1990). Mean height or top height of forest stand can be used for site quality determination. However, the definition of top height is not uniform in the forestry praxis. It can be expressed as an arithmetic average of over-storey trees or as a mean height of $10 \%$ (or $20 \%$ ) trees with top DBH. In addition, when the top height was used instead, the high variability was revealed and data was redundant. This can be explained by small number of trees on many inventory plots to calculate the top height. Thus, the mean height was applied for the study.

The total volume production per hectare is the most reliable indicator of site quality. It represents a total growing stock, which the stand is able to produce until particular age and on particular site (Šebík, Polák 1990). It does not depend on thinning type almost at all. But the 
problem is to assess a sum of thinning and measures that have been done so far. In our case it was not possible.

Tree species composition also influences a wood productivity. For example, the total wood production in unmixed beech stand is lower than that one in beech stands mixed with spruce (Wiedemann 1955 in Vyskot et al. 1971). Klíma (2007) revealed a relationship between percentage of beech and European larch and total stand production. With increasing a percentage of larch, the total production increases. Height and diameter growth of tree species in mixed stand (mean height, mean diameter) is not dependent on tree species composition level, but is only dependent on minimum abundance of species with less percentage. However, volume production of mixed stand depends on tree species composition level, but volume production of particular tree species converted on their percentage is not dependent on composition level (Vyskot et al. 1971).

We can state, that the elevation (to be considered in AVZ) and soil condition (nutrient status, moisture, base saturation - this is basis for EO distinguishing) are the main factors influencing a beech productivity. Piovesan et al. (2005) examined a beech growth with respect to elevation. Hierarchical clustering and principal component analysis of tree-ring chronologies generated distinct beech forest types. For each of those types, correlation between principal component scores and climate data revealed the most important climatic signals and their spatial extension. Distinctive radial growth-climate relationships uncovered in the tree-ring network are organized along altitudinal and latitudinal gradients. With regard to latitude, central and southern forests were clearly separated from northern ones. Three major beech bioclimatic zones (low-elevation, mountainous, highelevation) were distinguished. Other authors (Biondi 1993, Biondi, Visani 1996, Piovesan and Schirone 2000, Dittmar et al. 2003, Piovesan et al. 2003) revealed that the summer drought is the key climatic factor that affects beech growth. Lendzion and Leuschner (2008) concluded that vapour pressure deficit is a widely ignored factor which influences the growth and vitality, and possibly also the distribution of European beech. Hamilton (1995) revealed that topsoil depth, soil texture, subsoil consistence class, limiting layers, and fertility are of those factors with major impact on forest soil productivity and site index. Fekedulegn, Hicks, Colbert (2002) examined relationships between radial growth, topographic aspect, and precipitation for four hardwood species growing on contrasting aspects in north-central West Virginia. The study found that all species except northern red oak showed significant differences in growth between the northeast and southwest aspects $(P<0.05)$.

\section{Conclusion}

The forest typology (forest site classification) is of high importance in Slovakia and in foreign countries as well. In the present, the requirements for sustainable forest management (sustaining or increasing of the forest cover in the country, getting better of a management quality, protection of the forest ecosystems and individual biotopes, and others) and differentiated approaches in the silvicultural and harvesting techniques have being increased. Differentiated approach means the application of tailor-made management measures reflecting particular site types (i.e. potential productivity), current tree species composition of managed stands (whether natural or altered) and ecological conditions on regional or local level. Outputs of site mapping, as well as site-based knowledge and related regulations, can (or should) be crucial in this effort.

Current forest classification in Slovakia is based on the assessment of the potential vegetation, which, as believed, should reflect natural conditions of forest sites (soil conditions, climate, physiographic properties, and others) and should allow monitoring their changes. However, despite the wording of forest site type definition, Slovak classificiation is based mainly on a description of potential natural vegetation. But particular site type definitions usually do not contain clear rules how field worker should cope with current state of each particular site and forest stand on it, with man-induced changes to soil properties or tree species composition and productivity.

The aim of this paper was to analyze a beech productivity of Slovak ecology-based as well as management-based site units. As for the altitudinal vegetation zones, we identified three groups of these units, in which the beech productivity was quite homogenous. In the $3^{\text {rd }}, 4^{\text {th }}$ and $5^{\text {th }}$ altitudinal zones, which are grouped together, the fertile sites with higher beech productivity occur. The second group ( $2^{\text {nd }}$ AVZ) includes poorer sites at lower altitudes with lower beech productivity. Here, limiting factors affecting the beech productivity are mainly climatic ones (especially amount of precipitation). The third group includes the sites at higher altitudes 
( $6^{\text {th }}$ AVZ), where the temperature limits the growth of beech. In terms of soil properties, two or three groups of "ecological orders" can be recognized. The first one includes EO "A/B", "B/C" and "B", and second one EO "D". Considering the FSTMU, the situation is similar to previous ones (two groups, fertile one and poor one, can be recognized, generally).

In the forest stands with mean diameter up to $15-25 \mathrm{~cm}$ on poorer sites the higher growth (productivity) capability of beech was revealed. In the stands with mean diameter over $15-25 \mathrm{~cm}$ the higher productivity on fertile sites was found out.

In general, we can state that site units, analyzed in this study, reflect a site production capability explained by beech height growth. However, there is a possibility to group some of them in order to decrease a number of units. In general, we suggest using of only four groups of beech growth type: (1) fertile sites at the low-elevation (or altitudinal vegetation zones inferior); (2) poor sites at low-elevation; (3) fertile sites at high-elevation; (4) poor sites at high-elevation.

Site classification (based on ecology and productivity) is only a tool for management planning

\section{References}

Abella, S. R., Shelburne, V. B., MacDonald, N. W. 2003: Multifactor classification of forest landscape ecosystems of Jocassee Gorges, southern Appalanchian Mountains, South Carolina. Canadian Journal of Forest Research, 33: 1933-1946.

Allen, B. H. 1987: Ecological Type Classification for California: The Forest Service Approach. Gen. Tech. Rep. PSW-98. Berkely CA: Pacific Southwest Forest and Range Experiment Station, Forest Service, U.S. Department of Agriculture: 8 pp.

CAJANDER, A. K. 1949: Forest types and their significance. Acta Forestalia Fennica, 56 (5): 1-71.

BAJZAK, D., Roberts, D. A. 1996: Development of ecological land classification and mapping in support of forest management. Environmental Monitoring and Assessment, 39: 199-213.

Barnes, B. V., Zak, D. R., Denton, Sh. R., Spurr, S. H. 1998: Forest ecology. $4^{\text {th }}$ Edition. John Wiley and Sons, Inc., USA: 774 pp.

BIONDI, F. 1993: Climatic signals in tree-rings of Fagus sylvatica L. from the central Apennines, Italy. Acta Oecologica, 14: 57-71.

Biondi, F., Visani, S. 1996: Recent developments in the analysis of an Italian tree-ring and decision-making. Forest environmental and vegetation complexes vary continuously and effort to put a boundary is based on subjectivity (Abella et al. 2003). Resource managers need to know six attributes of a site to manage it effectively (Allen 1987): 1) Productive potential and expected response to management treatments; 2) Existing vegetation; 3) Land situation, such as geomorphic classification, slope gradient, slope aspect; 4) Juxtaposition to other land types and ownerships; 5) Current use; 6) Soil situation (taxonomy).

\section{Acknowledgement}

The data processing was supported within the project "Center of excellence for the support of decision making in forest and land", ITMS: 26220120069 , on the basis of support from Operational Programme Research and Development funded by European regional development fund and within the project No. APVV0255-10 supported by the Slovak Research and Development Agency.

network with emphasis on European beech (Fagus sylvatica L.). In: Dean, J.S., Meko, D.M., Swetnam, T.W. (Eds.), Tree Rings, Environment and Humanity, Special Volume. Radiocarbon, 713-725.

BryAn, A. B. 2006: Synergistic Techniques for Better Understanding and Classifying the Environmental Structure of Landscapes. Environmental Management, 37 (1): 126-140.

Buček, A., Lacina, J. 1999: Geobiocenologie II. [skripta]. Brno, MZLU, LDF: 240 s.

Dittmar, C., Zech,W., Elling,W. 2003: Growth variations of common beech (Fagus sylvatica L.) under different climatic and environmental conditions in Europe - a dendroecological study. Forest Ecology and Management, 173: 63-78.

Ellenberg, H. 1974: Zeigerwerte der Gefässpfanzen Mitteleuropas. Scripta Geobotanica, 9: 1-97.

FABRIKA, M. 2003: Rastový simulátor SIBYLA a možnosti jeho uplatnenia pri obhospodarovaní lesa. [Growth simulator SIBYLA and its possibilities of application to forest management] Lesnícky časopis - Forestry Journal, 49 (2): 135-151. 
Fekedulegn, D., Hicks, R. R., Colbert, J. J. 2002: Influence of topographic aspect, precipitation and drought on radial growth of four major tree species in an Appalachian watershed. Forest Ecology and Management, 177 (1-3): 409-425.

Halaj, J., Bortel, J., Grék, J., Mecko, J., Midriak, R., Petráš, R., Sobocký, E., TutKa, J., Valtýni, J. 1990: Rubnázrelost'drevín. [Rotation period of tree species] Príroda Bratislava, 115 s.

Halaj, J., PÁnek, F., Petráš, R. 1980: Rozbor rastových procesov rovnovekých nezmiešaných porastov. [Analysis of growth processes of evenaged homogeneous forest stands] Záverečná správa. Zvolen, VÚLH, 87 s.

Halaj, J., Pánek, F., Petrášs, R., Grék, J. 1980: Výskum a konštrukcia rastových tabuliek hlavných drevin ČSSR. [Research and construction of growth tables of main tree species of CSSR] Záverečná správa. Zvolen, VÚLH, 242 s.

Halaj, J., Petráš, R. 1998: Rastové tabul'ky hlavných drevin. [Growth tables of main tree species] SAP Press, Bratislava, 325 s.

HANČINSKÝ, L. 1972: Lesnétypy Slovenska. [Forest site types of Slovakia] Príroda, Bratislava, $307 \mathrm{~s}$.

Hemilton, R. A. 1995: Forest Soils and Site Index. Woodland Owner Notes, North Carolina Cooperative Extension Service, North Carolina State University: 6-7.

Kai, Y., Ying, M., HuiYan, G., Peng, L. 1999: Site classification of the eastern forest region of Daxing'an Mountains. Journal of Forestry Research, 10 (2): 129-131.

KLímA, S. 2007: Vliv různého zastoupení buku na jeho kvalitu a produkce ve směsi $s$ modrínem [Effects of the various proportion of beech on its quality and production in a mixture with larch]. Zprávy lesnického výzkити, 52 (1): 5-9.

KRIŽOVÁ, E. 1995: Fytocenológia a lesnícka typológia. [Phytocoenology and forest typology] Technická univerzita vo Zvolene, Zvolen, $180 \mathrm{~s}$.

KRIŽOvÁ, E., NIč, J. 1991: Fytocenológia a lesnícka typológia. [Phytocoenology and forest typology] Návody na cvičenia. TU Zvolen, 112 s.

KuKLA, J. 1993a: The direct determination of the geobiocen edaphic-trophic orders and interorders. Ecologia Bratislava, 12 (4): 373-385.

Kukla, J. 1993b: Theoretical possibilities of the direct geobiocens homeostatic trophotope determination. Ecology, 12 (4):361-371.

LaRsen, D. R., Hann, D. W. 1987: Height-diameter eqations for seventeen tree species in Southwest Oregon. Forest Research Laboratory, Oregon
State University, Corvallis. Research Paper 49, 16 pp.

Lendzion, J., Leuschner, Ch. 2008: Growth of European beech (Fagus sylvatica L.) saplings is limited by elevated atmospheric vapour pressure deficits. Forest Ecology and Management, 256 (4): 648-655.

Merganič, J., VorČák, J., Merganičová, K., Ďurský, J., Miková, A., ŠKvarenina, J., TučeK, J., MinĎÁš, J. 2003: Monitoring diverzity horských lesov severnej Oravy. [Monitoring of diversity of mountains forests in Northern Orava] EFRA. Tvrdošín: 200 s.

Pagan, J. 1999: Lesnícka dendrológia. [Forest dendrology] Vysokoškolské skriptá. TU Zvolen: $378 \mathrm{~s}$.

Piovesan, G., Schirone, B. 2000: Winter North Atlantic Oscillation effects on the tree rings of the Italian beech (Fagus sylvatica L.). International Journal of Biometeorology, 44: 121-127.

Piovesan, G., Bernabei, M., Di Filippo, A., Romagnoli, M., Schirone, B. 2003: A long-term tree ring beech chronology from a high elevation old-growth forest of Central Italy. Dendrochronologia, 21: 1-10.

Piovesan, G., Biondi, F., Bernabei, M., Filippo, A., Schirone, B. 2005: Spatial and altitudinal bioclimatic zones of the Italian peninsula identified from a beech (Fagus sylvatica L.) tree-ring network. Acta Oecologica, 27 (3): 197-210.

RandušKa, D., Vorel, J., Plíva, K. 1986: Fytocenológia a lesnícka typológia. [Phytocoenology and forest typology]. Príroda, Bratislava, 344 s.

Ray, D. 2001: Ecological Site Classification. A PCbased Decision Support System for British Forests. User's guide, Version 1.7. Crown, UK, 44 pp.

Rowe, J. S. 1996: Land classification and ecosystem classification. Environmental Monitoring and Assessment, 39: 11-20.

StatSoft, Inc. 2005: STATISTICA CZ [Software for data analysis], verze 7.l. www.StatSoft.cz.

Schwarz, M. Lesoprojekt [Internet]. SK: National Forest Centre; 2009 March 23; Available from: http://www.lesoprojekt.sk/english/ default.htm.

ŠĖík, L., PolÁK, L. 1990: Náuka o produkcii dreva. [Wood production] Príroda Bratislava, $322 \mathrm{~s}$.

Šmelko, Š., Wenk, G., Antanaitis, V. 1992: Rast, štruktúra a produkcia lesa. [Growth, structure, and production of forest] Príroda Bratislava, $319 \mathrm{~s}$.

Šmelko, Š., Merganič, J., Šebeñ, V., Raši, R., Jankovič, J. 2006: Národná Inventarizácia a monitoring lesov Slovenskej republiky 2005- 
2006. [National Forest Inventory and Monitoring in Slovak Republic 2005 - 2006] Metodika terénneho zberu údajov. [Methodology of field data collection] 3. doplnená verzia. NLC Zvolen, $129 \mathrm{~s}$.

Vyskot, M., Doležal, B., JurČa, J., Korf, V., Korpel, Š., Macháč, D., Polák, L., Priesol, A., ŘehÁK, J., Wolf, J. 1971: Základy rüstu a produkce lesio. [Fundamentals of forest growth and production] SZN Praha, $440 \mathrm{~s}$.

Zlatník, A. 1959: Přehled slovenských lesu podle skupin lesnich typu. [Overview of Slovak forests according to forest site type groups] LF VŠZ Brno, 195 s.

Zlatník, A. 1976: Lesnická fytologie. [Forest phytology] SZN Praha, 495 s. 